\title{
Curricular Goals and Personal Goals in Master's Thesis Projects:
}

\section{Dutch Student-Supervisor Dyads}

\author{
Renske A.M. de Kleijn ${ }^{1}$, Paulien C. Meijer ${ }^{1}$, Mieke Brekelmans ${ }^{1} \&$ Albert Pilot $^{1}$ \\ ${ }^{1}$ Utrecht University, PO box 80127, 3508 TC Utrecht, The Netherlands \\ Correspondence: Utrecht University, PO box 80127, 3508 TC Utrecht, The Netherlands. Tel: 31-30-253-1613. \\ E-mail: R.A.M.deKleijn@uu.nl
}

Received: November 16, 2012

Accepted: December 12, 2012

Online Published: December 14, 2012

doi:10.5430/ijhe.v2n1p1

URL: http://dx.doi.org/10.5430/ijhe.v2n1p1

\begin{abstract}
To be effective, feedback should be goal-related. In order to better understand goal-related feedback in Master's thesis projects, the present study explores the goals of supervisors and students in supervision dyads and similarities and differences within and between these dyads. Twelve supervisors and students were interviewed, and their goals were categorized using a curricular perspective and personal goals perspective. Results indicated that most students and supervisors pursue both curricular and personal goals, which is explained with the transitional phase from being a student to becoming a professional. Within dyads goals of supervisors and students vary greatly and supervisors recognize students' curricular goals better than students' personal goals. The findings suggest that goal-related feedback in Master's thesis supervision can be complex, as students and supervisors (1) can pursue different goals and (2) do not always correctly perceive each other's goals.
\end{abstract}

Keywords: Supervision, Goals, Perceptions, Master's thesis, Alignment

\section{Introduction}

In most higher education institution in Europe a Master's thesis is the final element of a Master's degree (Meeus, van Looy, \& Libotton, 2004). In most cases a Master's thesis project is characterized by a substantial research component, of which the learner determines the direction through prolonged engagement and with the support of a supervisor (Todd, Bannister, \& Clegg, 2004). The quality of the supervision process is deemed one of the most important factors contributing to a successful project (e.g., Seagram, Gould, \& Pyke, 1998), and providing effective feedback is an important task for the supervisor (e.g., Dysthe, Samara, \& Westrheim, 2006). Research has indicated that effective feedback is, among other things, goal-related (e.g., Hattie \& Timperley, 2007); which means that feedback should provide information to the learner about what the goals are, how a student's performance or understanding relates to the goals, and what a student can improve to better reach those goals (e.g., Sadler, 1998). In a previous study in which 1028 Master's students' perceptions of their Master's thesis supervisors were surveyed, we found that in terms of goal-relatedness they perceived their feedback to provide only limited feed up, i.e., clarification of the goals (de Kleijn, Mainhard, Meijer, Brekelmans, \& Pilot, 2012). In order to understand what goal-related feedback with feed up means in the context of Master's thesis projects and how goal-relatedness might be improved, as a first step it is important to gain insight in what the goals of a Master's thesis project are for those involved.

In literature the main goal of higher education in general is often described as preparing students for a successful career in working life and thus a good position on the labour market (Livanos, 2010; Marita \& Felix, 2010). In the specific context of Master's thesis projects, goals described in the literature include learning, assessing, and self-regulation (de Kleijn et al., 2012); students are supposed to learn to conduct and report a piece of research, students are supposed to learn to work rather independently, and students are assessed in terms of whether they meet the standards and are worthy of a Master's degree. However, as feedback is usually provided during face-to-face meetings between a supervisor and a student, not only such curricular goals are important for understanding and improving goal-related feedback, but also the goals that are pursued by the specific supervisor and student who are the active agents in the supervision process and thus in the feedback dialogue. 
Furthermore, we assume that in order for feedback to be provided and perceived as goal-related it is important for supervisor and student to know each other's goals. If students and supervisors work towards different goals, there could be misunderstandings or miscommunications during the supervision process. Indeed, Collier and Morgan (2008) and Lovvitts (2007) emphasized the importance of students correctly understanding what professors or supervisors expect of them, in order to achieve a good performance. One can imagine that when a supervisor and student have different goals without being aware of it, feedback might be provided and perceived from different perspectives, leading to the feedback process being perceived as not goal-related. The present study therefore aims to provide insight into the specific goals pursued by both supervisors and students in supervision dyads and into the extent to which they know each other's goals, addressing the following three research questions:

1) What goals do students and supervisors in a supervision dyad have for a Master's thesis project?

2) What are similarities and differences between supervisor and student goals within and between dyads?

3) How do supervisor's goals relate to the student's perceptions of supervisor goals and how do student's goals relate to the supervisor's perceptions of student goals?

\section{Theoretical framework}

\subsection{Conceptualizing goals in higher education}

Following the motivational systems theory (Ford, 1992), we understand goals to 'represent the consequences to be achieved (or avoided), and they direct the other components of the person to try to produce those consequences (or prevent them for occurring)' (p. 83). In other words, goals are consequences to be achieved and are expected to steer behaviour so that these are indeed achieved. We also assume that one's goals influence how the behaviour of other people is interpreted.

A considerable number of studies have investigated student goals in higher education (e.g., Litmanen, Hirsto, \& Lonk,a 2010; Mikkonen, Ruohoniemi, \& Lindblom-Ylänne, in press; Pintrich, 2000; Vandewalle, 1997). Based on the work of Pintrich (2000) two goal-orientations are often distinguished: a mastery (also learning) goal-orientation and a performance goal-orientation. However, recently several researchers distinguished more types of goals; work-related, social enhancement and social affiliation goals ( $\mathrm{Ng}, 2008)$; qualification, study process, study success, and other goals (Litmanen et al., 2010). Indeed, especially given the fact that students working on their Master's thesis are in a transitional period in their life (from student to professional), we think a more elaborate view of goals is appropriate, that is a view that includes more than only curricular goals. This is in line with the reasoning of Boekaerts, de Koning, and Vedder (2008) who propose three conceptual frameworks to be used when investigating goals in educational contexts, in order to do more justice to the complexity and variety of goals in education; Ford and Nichols' (1991) taxonomy of human goals to describe the different content of goals that might interact in classrooms, Carver and Scheier's (2000) hierarchical goal model to describe the links that students might establish between different content goals, and Schwartz's (1992) trans-situational value structure to examine contextual effects on goal orientation and engagement. As this study explores the content of goals, Ford and Nichol's taxonomy was used in addition to a framework for curricular goals.

\subsubsection{Curricular goals}

In order to describe curricular goals, we chose to use the Dublin descriptors. These describe the generally expected attributes of students who have completed a Bachelor's, Master's or doctoral degree. For each qualification, attributes are described in terms of 'knowledge and understanding', 'applying knowledge and understanding', 'making judgments', 'communication', and 'learning skills'. We consider these five attributes to be highly relevant for Master's thesis projects. The Dublin descriptors framework was developed as part of the Bologna process which aims, among other things, to improve the compatibility, comparability and competitiveness of higher education institutions across Europe (Gänzle, Meister, \& Kind, 2009). These shared goals were developed in the form of the Dublin descriptors (Joint Quality Initiative, 2004). We will use the framework, because we think it is a suitable overview of curricular goals in higher education (see Table 1).

\subsubsection{Taxonomy of human goals}

In order to describe goal content, Ford and Nichols developed a taxonomy of human goals $(1987 ; 1991 ; 1992 ; 2007$; see Table 2). In this taxonomy a distinction is made between within-person goals on the one hand, referring to the person themselves, and person-environment goals on the other hand, referring to the relationship between person and environment. The within-person goals are subdivided into affective goals, cognitive goals, and subject organization 
goals. The person-environment goals are subdivided into self-assertive social relationship goals, integrative social relationship goals, and task goals.

Relating the goals in this taxonomy to distinctions made in goal-orientation research, a performance goal orientation can be seen in categories such as individuality, superiority, and resource acquisition. Work-related goal orientation can be seen in the resource provision category, social goals are also represented in the taxonomy. There is also a category labelled mastery, however, in goal-orientation literature mastery is described as a focus on the learning of a skill (e.g., Pintrich, 2000), whereas in this taxonomy mastery it is also about meeting a challenging standard. Applied to an educational context, meeting the standard indicates achieving a sufficient grade in order to pass. Cognitive goals are also described: exploration, understanding, intellectual creativity, and positive self-evaluations. However, instead of using these general cognitive goals to describe supervisor and student goals in a Master's thesis project, we use the Dublin descriptors framework. We thus replace the cognitive goals of the taxonomy for human goals with the Dublin descriptors framework.

\subsection{Student and supervisor goals in Master's thesis projects}

With respect to student goals, Anderson et al. (2008) interviewed fifteen professional part-time students involved in a Master's thesis project, and found three categories of goals that were all intrinsic in nature: a strong wish to advance practice through the results of the thesis (practice intrinsic), a desire to make intellectual progress (academic research intrinsic), and a satisfying sense of personal involvement, development and/or change (personal intrinsic). In contrast, based on 72 student interviews Ylijoki (2001) described four narratives about the way students experienced their Master's thesis projects; heroic, business-like, tragic, and penal. In the 'penal' narrative, she describes students who do not understand why a thesis should be written in the first place. These students experienced their thesis merely as punishment. The findings of both Anderson et al. and Ylijoki suggest that students can have different views on, and goals for, a Master's thesis.

With respect to supervisor goals Anderson et al. (2006) interviewed 13 supervisors who had a local reputation for competence. Their main goals for students were to align them to the routines of the research community by disembedding them from the assumptive world of everyday contexts, adopting an open and questioning perspective, and to encourage them to follow academic conventions in order to be able to actively defend their stance on a topic. Furthermore, the supervisors interviewed wanted their students to exercise responsibility for progressing the thesis and to show commitment to their project. Some supervisors found it important that the thesis had an impact on practice, even though others found the student development towards achieving a critical and reflective intellectual stance to be the most salient goal of the thesis process. In general, no specific differences between disciplines were found in previous research (e.g., Anderson et al., 2006; Ylijoki, 2001).

In these previous studies concerning student and supervisor goals, independent groups of students and supervisors were sampled. In the present study supervisors and students are selected in dyads, in order to gain insight into the nature of and variation in goals of dyads that actually are working together on a Master's thesis project. Furthermore, goals were studied bottom up, whereas in this study existing goal frameworks are used.

\section{Methods}

\subsection{Participants}

Supervisors with a local reputation for being good supervisors were invited to participate in the present study. In order to generate some variance between these good supervisors, we included supervisors from three faculties of a large Dutch university; Social and Behavioural Sciences, Geosciences, and Humanities. Fifteen supervisors were selected with a local reputation for being successful in the role of supervisor as indicated by the Dean of the faculty. Twelve supervisors agreed to participate and they each selected one of their Master's students who were being supervised at the time and whose supervision process was perceived as being representative. All these students agreed to participate.

Two supervisors and eight students were female. Students were between 23 and 35 years old and had taken part in 1 - 20 supervision meetings at the time of the interview. The supervisors ranged from being $\mathrm{PhD}$ students to full professors.

\subsection{Procedure and instrumentation}

For each dyad, we interviewed both student and supervisor separately immediately after a supervision meeting. During these interviews, supervisors were asked what the main goal(s) of a Master's thesis project was for them and what they perceived to be the main goal(s) of a Master's thesis project for their students. Students were also asked 
about the main goals of their Master's thesis project and what they perceived their supervisor's goal(s) to be. The interview questions were piloted to check their comprehensibility for the respondents.

\subsection{Analysis}

The analysis of the interview data was performed according to the following steps. In order to establish the unit of analysis in the transcribed answers of both students and supervisors to both questions, the goals (both students' and supervisors' own and perceived other's goals) were first selected per person per question. Along with the transcribed answers, these selections were then given to a second and independent researcher, who checked the selections for completeness (are all important elements of the transcribed answer included in the selection?) and visibility (are all elements of the selection visible in the transcribed data?). This resulted in 102 goals in total.

The goals were then coded, using the five Dublin descriptors as a starting point (see Table 1). Goals that could not be coded as belonging to a descriptor were coded using the goal taxonomy of Ford and Nichols (see Table 2). We could thus clearly distinguish educational goals from additional personal goals. The data was coded by the first author and a third, independent, researcher. Based on a discussion of these codings some additional

coding rules were described in order for reliable coding to be possible. An extra category was described as imposed/external goal (e.g., 'it is just an obligatory part of the educational programme'). Two supervisor goals, as perceived by students, could not be coded with either of the two frameworks because these students described what the supervisors themselves wanted to achieve with a student's Master's thesis rather than what the supervisors wanted the students to achieve; one student described a perceived supervisor goal as providing the best supervision they possibly could, and another student suggested that the supervisor wanted to make students enthusiastic about becoming one of their PhD students after their Master's. One supervisor also indicated that he found it too difficult to describe the student's goals as he perceived them.

Finally, the first author coded the data again and codings were compared to the codings of a fourth and independent researcher. This resulted in a Cohen's kappa of 0.89 for the Dublin descriptors and 0.76 for the Ford and Nichols goal taxonomy.

Table 1. Coding scheme based on Dublin descriptors for the Master's level as described by the NVAO

\begin{tabular}{|l|l|l|}
\hline Dublin descriptor & \multicolumn{1}{|c|}{ Description of Master's qualification } & \multicolumn{1}{|c|}{ Example from data } \\
\hline $\begin{array}{l}\text { Knowledge and } \\
\text { understanding }\end{array}$ & $\begin{array}{l}\text { Has knowledge and understanding, based on } \\
\text { knowledge and understanding of the Bachelor's } \\
\text { degree that exceeds and deepens this, and also a basis } \\
\text { to make an original contribution to the development } \\
\text { or application of ideas, often in the context of } \\
\text { research. }\end{array}$ & $\begin{array}{l}\text { 'I want to broaden my } \\
\text { knowledge of research.' } \\
\text { (student) }\end{array}$ \\
\hline $\begin{array}{l}\text { Applying knowledge } \\
\text { and understanding }\end{array}$ & $\begin{array}{l}\text { Is able to apply knowledge and understanding in new } \\
\text { or unknown circumstance within a broader (or } \\
\text { multidisciplinary) context that is related to the field of } \\
\text { study; is able to integrate knowledge with complex } \\
\text { information. }\end{array}$ & $\begin{array}{l}\text { 'Students should show that } \\
\text { they can apply everything } \\
\text { they have learned before.' } \\
\text { (supervisor) }\end{array}$ \\
\hline Making judgments & $\begin{array}{l}\text { Is able to formulate a judgment based on incomplete } \\
\text { or minimal information, considering social and } \\
\text { ethical responsibilities, that are connected to the } \\
\text { application of the own knowledge and judgments. }\end{array}$ & $\begin{array}{l}\text { 'This is the moment that } \\
\text { their critical thinking will } \\
\text { crystallize.' } \\
\text { (supervisor) }\end{array}$ \\
\hline Communication & $\begin{array}{l}\text { Is able to communicate conclusions clearly and } \\
\text { unambiguously to a public of specialists and } \\
\text { non-specialists, as well as the knowledge, motives } \\
\text { and considerations that underlie these conclusions. }\end{array}$ & $\begin{array}{l}\text { 'Students should be able to } \\
\text { write in an accessible and } \\
\text { convincing way.' } \\
\text { (supervisor) }\end{array}$ \\
\hline Learning skills & $\begin{array}{l}\text { Has the learning skills that put him/her in the position } \\
\text { that (s)he can do a follow up programme with a } \\
\text { largely self-directed or autonomous character. }\end{array}$ & $\begin{array}{l}\text { 'I want to learn to work } \\
\text { independently.' } \\
\text { (student) }\end{array}$ \\
\hline
\end{tabular}


Table 2. Coding scheme based on taxonomy of human goals (Ford \& Nichols, 1991)

\begin{tabular}{|c|c|c|}
\hline \multicolumn{2}{|r|}{ Desired within-person consequences } & Example from data \\
\hline \multicolumn{3}{|l|}{ Affective Goals } \\
\hline Entertainment & $\begin{array}{l}\text { Experiencing excitement or heightened arousal; } \\
\text { Avoiding boredom or stressful inactivity }\end{array}$ & $\begin{array}{l}\text { 'For me it's just fun, a } \\
\text { hobby.' (student goal) }\end{array}$ \\
\hline Tranquillity & $\begin{array}{l}\text { Feeling relaxed and at ease; Avoiding stressful } \\
\text { over-arousal }\end{array}$ & - \\
\hline Happiness & $\begin{array}{l}\text { Experiencing feelings of joy, satisfaction, or } \\
\text { well-being; Avoiding feelings of emotional distress or } \\
\text { dissatisfaction }\end{array}$ & $\begin{array}{l}\text { 'I think the student him } \\
\text { or herself should be } \\
\text { satisfied with the project' } \\
\text { (supervisor goal) }\end{array}$ \\
\hline Bodily sensations & $\begin{array}{l}\text { Experiencing pleasure associated with physical } \\
\text { sensation, physical movements, or bodily contact; } \\
\text { Avoiding unpleasant or uncomfortable bodily } \\
\text { sensations }\end{array}$ & - \\
\hline Physical well-being & $\begin{array}{l}\text { Feeling healthy, energetic, or physically robust; } \\
\text { Avoiding feelings of lethargy, weakness, or ill health }\end{array}$ & - \\
\hline \multicolumn{3}{|l|}{ Cognitive Goals } \\
\hline Exploration & $\begin{array}{l}\text { Satisfying one's curiosity about personally meaningful } \\
\text { events; Avoiding a sense of being uninformed or not } \\
\text { knowing what's going on }\end{array}$ & - \\
\hline Understanding & $\begin{array}{l}\text { Gaining knowledge or making sense out of something; } \\
\text { Avoiding misconceptions, erroneous beliefs, or } \\
\text { feelings of confusion }\end{array}$ & - \\
\hline Intellectual creativity & $\begin{array}{l}\text { Engaging in activities involving original thinking or } \\
\text { novel or interesting ideas; Avoiding mindless or } \\
\text { familiar ways of thinking }\end{array}$ & $\begin{array}{l}\text { 'I think my supervisor } \\
\text { wants to breed an } \\
\text { academic attitude.' } \\
\text { (student perception) }\end{array}$ \\
\hline $\begin{array}{l}\text { Positive } \\
\text { self-evaluations }\end{array}$ & $\begin{array}{l}\text { Maintaining a sense of self-confidence, pride, or } \\
\text { self-worth; Avoiding feelings of failure, guilt, or } \\
\text { incompetence }\end{array}$ & $\begin{array}{l}\text { 'Purely to prove to } \\
\text { myself that I can write a } \\
\text { thesis.' (student goal) }\end{array}$ \\
\hline \multicolumn{3}{|c|}{ Subject Organization Goals } \\
\hline Unity & $\begin{array}{l}\text { Experiencing a profound or spiritual sense of } \\
\text { connectedness, harmony, or oneness with people, } \\
\text { nature, or a greater power; Avoiding feelings of } \\
\text { psychological disunity or disorganization }\end{array}$ & - \\
\hline Transcendence & $\begin{array}{l}\text { Experiencing optimal or extraordinary states of } \\
\text { functioning; Avoiding feeling trapped within the } \\
\text { boundaries of ordinary experience. }\end{array}$ & - \\
\hline \multicolumn{2}{|c|}{ Desired person-environment consequences } & \\
\hline \multicolumn{3}{|c|}{ Self-Assertive Social Relationships Goals } \\
\hline Individuality & $\begin{array}{l}\text { Feeling unique, special, or different; Avoiding similarity } \\
\text { or conformity with others }\end{array}$ & $\begin{array}{l}\text { 'I think it is important } \\
\text { that students really } \\
\text { present themselves.' } \\
\text { (supervisor goal) }\end{array}$ \\
\hline Self-determination & $\begin{array}{l}\text { Experiencing a sense of freedom to act or make choices; } \\
\text { Avoiding the feeling of being pressured, constrained, or } \\
\text { coerced }\end{array}$ & $\begin{array}{l}\text { 'I find it important for } \\
\text { students to do their own } \\
\text { thing.' (supervisor goal) }\end{array}$ \\
\hline
\end{tabular}


Table 2. Coding scheme based on taxonomy of human goals (Ford \& Nichols, 1991; continued)

\begin{tabular}{|c|c|c|}
\hline \multicolumn{2}{|r|}{ Desired person-environment consequences } & \multirow{2}{*}{$\begin{array}{c}\text { Example from data } \\
-\end{array}$} \\
\hline Superiority & $\begin{array}{l}\text { Comparing favourably to others in terms of winning, } \\
\text { status, or success; Avoiding unfavourable comparisons } \\
\text { with others }\end{array}$ & \\
\hline $\begin{array}{l}\text { Resource } \\
\text { acquisition }\end{array}$ & $\begin{array}{l}\text { Obtaining approval, support, assistance, advice, or } \\
\text { validation from others; Avoiding social disapproval or } \\
\text { rejection }\end{array}$ & $\begin{array}{l}\text { 'I mean, this is the final } \\
\text { judgment on my research } \\
\text { skills.' (student goal) }\end{array}$ \\
\hline \multicolumn{3}{|c|}{ Integrative Social Relationship Goals } \\
\hline Belongingness & $\begin{array}{l}\text { Building or maintaining attachments, friendships, } \\
\text { intimacy, or a sense of community; Avoiding feelings of } \\
\text { social isolation or separateness }\end{array}$ & - \\
\hline $\begin{array}{l}\text { Social } \\
\text { responsibility }\end{array}$ & $\begin{array}{l}\text { Keeping interpersonal commitments, meeting social role } \\
\text { obligations, and conforming to social and moral rules; } \\
\text { Avoiding social transgressions and unethical or illegal } \\
\text { conduct }\end{array}$ & - \\
\hline Equity & $\begin{array}{l}\text { Promoting fairness, justice, reciprocity, or equality; } \\
\text { Avoiding unfair or unjust actions }\end{array}$ & - \\
\hline Resource provision & $\begin{array}{l}\text { Giving approval, support, assistance, advice, or } \\
\text { validation to others; Avoiding selfish or uncaring } \\
\text { behaviour }\end{array}$ & $\begin{array}{l}\text { 'She really wants to } \\
\text { contribute to the field of } \\
\text { practice.' (supervisor } \\
\text { perception) }\end{array}$ \\
\hline \multicolumn{3}{|l|}{ Task Goals } \\
\hline Mastery & $\begin{array}{l}\text { Meeting a challenging standard of achievement or } \\
\text { improvement; Avoiding incompetence, mediocrity, or } \\
\text { decrements in performance }\end{array}$ & $\begin{array}{l}\text { 'They should show that } \\
\text { they are little } \\
\text { research-ers.' (supervisor } \\
\text { goal) }\end{array}$ \\
\hline Task creativity & $\begin{array}{l}\text { Engaging in activities involving artistic expression or } \\
\text { creativity; Avoiding tasks that do not provide } \\
\text { opportunities for creative action }\end{array}$ & - \\
\hline Management & $\begin{array}{l}\text { Maintaining order, organization, or productivity in daily } \\
\text { life tasks; Avoiding sloppiness, inefficiency, or } \\
\text { disorganization }\end{array}$ & - \\
\hline Material gain & $\begin{array}{l}\text { Increasing the amount of money or tangible goods one } \\
\text { has; Avoiding the loss of money or material possessions }\end{array}$ & - \\
\hline Safety & $\begin{array}{l}\text { Being unharmed, physically secure, and free from risk; } \\
\text { Avoiding threatening/depriving/harmful circumstances }\end{array}$ & - \\
\hline
\end{tabular}

\section{Results}

Table 3 presents students' and supervisors' own goals and their perceptions of the goals of the other actor in the supervision dyad in terms of the Dublin descriptors and the goal taxonomy of Ford and Nichols (1991). In general it was found that with respect to their own goals most supervisors and some students reported more than one goal. Two cells in the table are empty, as a student described a goal from the supervisor perspective and one supervisor indicated that (s)he could not indicate respectively the student's goal(s).

\subsection{Student goals and supervisor goals}

For the supervisors, 20 out of the 29 supervisor goals fitted one of the Dublin descriptors, whereas for students only 10 out of 24 student and supervisor goals fitted the Dublin descriptors. This suggests that students seem to be less concerned with curricular goals than supervisors. Within the Dublin descriptors, supervisors mainly focused on applying knowledge and understanding, whereas students mainly focused on gaining knowledge and understanding. 
With respect to the additional personal goals that were mentioned, resource acquisition was mentioned several times by both supervisors and students. Resource acquisition was mostly described in terms of gaining a diploma or validation that they are capable of doing research. Interestingly, three students also described a within-person (i.e., within-student) goal such as entertainment or positive confirmatory self-evaluations, but none of the supervisors did so. These are rather intrinsic goals. On the other hand, three students described the Master's thesis as an imposed assignment that they felt they had to complete, which could be considered as extrinsic.

On a dyadic level, for half of the dyads a shared goal was found, i.e., supervisor and student described the same goal. Still, in these dyads only one goal was shared and in the other six dyads no shared goals were found.

\subsection{Matches between goals and perceptions}

We compared supervisor goals with student perceptions of supervisor goals. In total we found six dyads in which the students correctly perceived one of their supervisor's goals. In two dyads this concerned the goal applying and understanding, and in the other dyads the correctly perceived goal varied. Surprisingly, none of the students perceived learning skills (working independently) to be an important goal whereas four supervisors described this goal. Connected to learning skills is self-determination, mostly described in the sense that students should feel ownership over their thesis project and should feel the freedom to do what they want to do. No student perceived this to be a supervisor goal, whereas two supervisors described this goal. This seems to indicate that students do not recognize learning to work independently or being the owner of their thesis as an important supervisor goal.

Comparing student goals and supervisor perceptions of student goals, we found four dyads in which the supervisors correctly perceived on of their student's goals. Interestingly, in three out of the four instances this concerned the goal resource acquisition, i.e., acquiring a diploma or degree.

Table 3. Supervisor and student goals and perceptions represented per supervision dyad

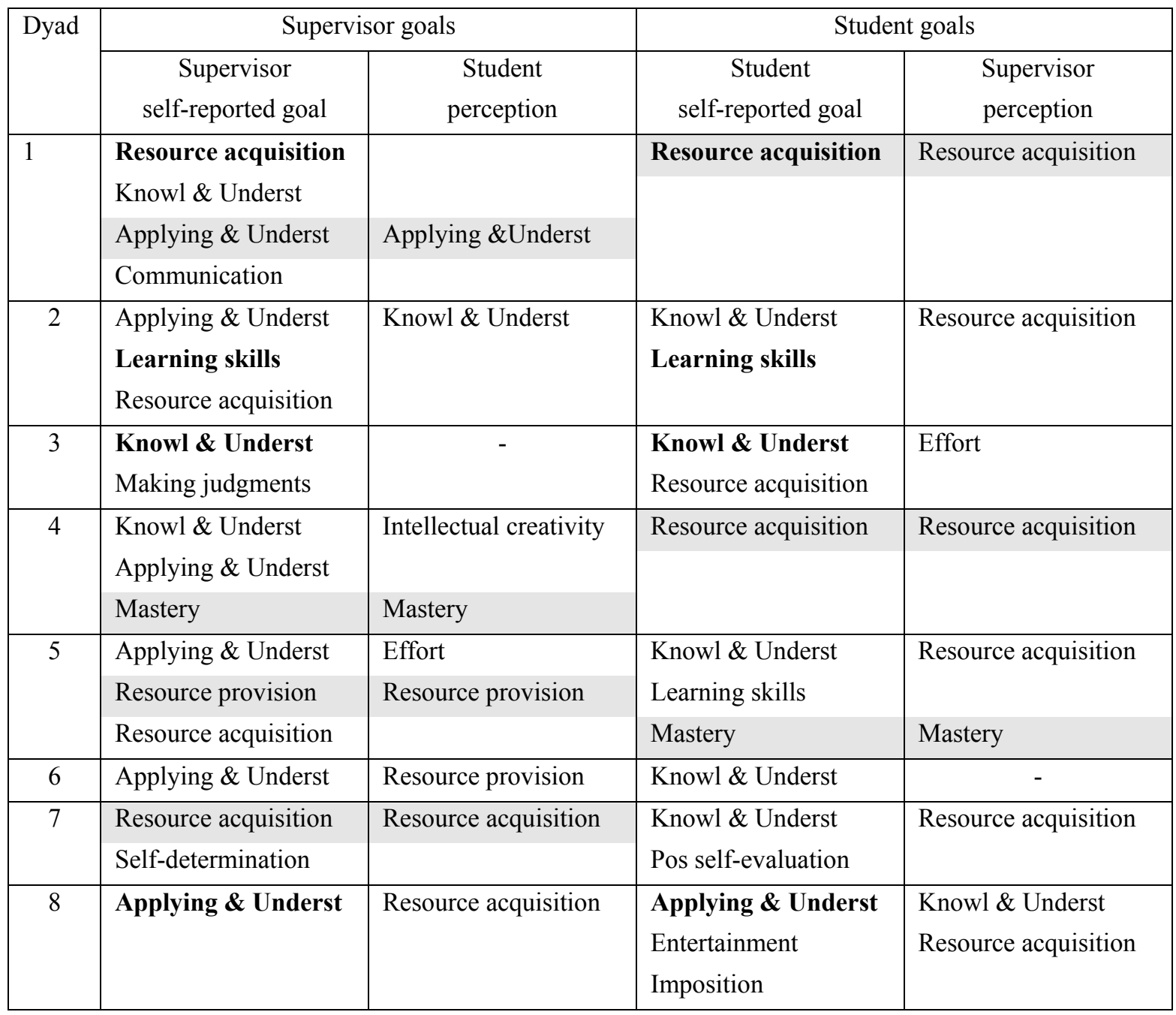


Table 3. Supervisor and student goals and perceptions represented per supervision dyad (continued)

\begin{tabular}{|c|c|c|c|c|}
\hline \multirow[t]{2}{*}{ Dyad } & \multicolumn{2}{|c|}{ Supervisor goals } & \multicolumn{2}{|c|}{ Student goals } \\
\hline & $\begin{array}{c}\text { Supervisor } \\
\text { self-reported goal }\end{array}$ & $\begin{array}{l}\text { Student } \\
\text { perception }\end{array}$ & $\begin{array}{c}\text { Student } \\
\text { self-reported goal }\end{array}$ & $\begin{array}{l}\text { Supervisor } \\
\text { perception }\end{array}$ \\
\hline \multirow[t]{2}{*}{9} & Applying \& Underst & Applying \& Underst & \multirow{2}{*}{$\begin{array}{l}\text { Applying \& Underst } \\
\text { Resource acquisition }\end{array}$} & \multirow[t]{2}{*}{ Self-determination } \\
\hline & $\begin{array}{l}\text { Learning skills } \\
\text { Individuality }\end{array}$ & & & \\
\hline \multirow[t]{2}{*}{10} & Knowl \& Underst & Knowl \& Underst & Resource acquisition & Resource acquisition \\
\hline & Communication & Effort & $\begin{array}{l}\text { Mastery } \\
\text { Pos self-evaluation }\end{array}$ & Knowl \& Underst \\
\hline 11 & $\begin{array}{l}\text { Self-determination } \\
\text { Applying \& Underst } \\
\text { Learning skills }\end{array}$ & $\begin{array}{l}\text { Mastery } \\
\text { Happiness }\end{array}$ & $\begin{array}{l}\text { Self-determination } \\
\text { Resource acquisition }\end{array}$ & Resource provision \\
\hline 12 & $\begin{array}{l}\text { Applying \& Underst } \\
\text { Learning skills }\end{array}$ & Resource acquisition & $\begin{array}{l}\text { Knowl \& Underst } \\
\text { Self-determination }\end{array}$ & Resource acquisition \\
\hline
\end{tabular}

Note. Bold indicates supervisor and student have this goal in common; Shades indicate goal and perception are the same. A minus (-) indicates missing data.

\section{Discussion}

Related to the first research question concerning students' and supervisors' own goals, we expected that in Master's thesis projects not only curricular goals (as described by the Dublin descriptors) would play a role for the students, but also other personal goals. Indeed we found that part of the supervisor and student goals could be described in terms of the Dublin descriptors, mainly knowledge and understanding, the application of knowledge and understanding, and learning skills. In addition, a substantial number of goals were found to be personal goals. And relatively, for students we found more personal goals than for supervisors. So confirming our expectation, we found that goals in a Master's thesis project go beyond curricular goals such as the Dublin descriptors, and therefore empirically confirm the suggestion of Boekaerts, de Koning, and Vedder (2006) that goals in education should not only be addressed from a curricular or educational perspective, but also from a perspective beyond that. This might be specifically important in the context of Master's thesis projects as students are in a transitional phase from being a student pursuing curricular goals, to becoming a professional pursuing personal goals.

Furthermore, other studies have found or argued that three prominent goals of the Master's thesis are assessment, learning, and self-regulation (Anderson et al., 2006; de Kleijn, Mainhard, Meijer, Pilot, \& Brekelmans, 2012; Todd et al., 2004; Nelson, 1997; Sachs, 2002). These three goals were also found in the present study, but can be described more specifically given the detailed coding schemes; assessment was found in terms of the thesis being an imposed or external goal and being a way to acquire a degree (a resource) with which to enter the labour market; learning was found in the Dublin descriptors, which specify what should be learned, which was mainly knowledge and understanding and/or the application of knowledge and understanding; and self-regulation was found as a learning skill to be learned and as self-determination. Thus, our findings confirm the goals that were described in previous studies, but more importantly provide a more nuanced view of how students and supervisors talk about these goals and shed light on other goals that can be pursued, such as resource provision, imposition and positive self-evaluations. Furthermore, Ford and Nichols' (1991) taxonomy of human goals proved to be a valuable instrument for analysing students' and supervisors' goals in higher education that go beyond a curricular perspective.

Concerning the second research question which addressed similarities and differences between supervisor and student goals within and between dyads, some similarities but mainly differences were found. In half of the dyads we found one shared goal. Not having shared goals, might be problematic since, as described before, working towards different goals could potentially lead to misunderstanding and miscommunication (Collier \& Morgan, 2008; Lovitts, 2007). More specifically, students focus mainly on knowledge and understanding whereas supervisors often focus on applying knowledge and understanding. This corresponds to the study of Murtonen, Olkunuora, Tynjäla, and Lethinen (2008) who found that students from the USA and Finland are not convinced that they will need research 
skills in working life, and therefore might focus more on learning new content and understanding theories rather than applying them in a research project. In addition, both students and supervisors see the thesis as a way to acquire resources, and some students see the thesis mainly as an imposed task.

The third research question concerned the relationship between supervisor and student goals on the one hand and the corresponding perceptions of their goals on the other hand. Our findings indicated that student's and supervisors' goals are sometimes perceived as such by the other, but that a lot of supervisor and student goals are not known by the other half of the dyad. Apparently, students do not seem to be aware of the fact that supervisors want them to work rather independently and that knowledge and understanding should not only be gained but most importantly should be applied. Here we might have an explanation for an earlier finding, that feedback is rarely perceived as goal-related (de Kleijn et al., 2012), as students seem to have no clear idea of what is expected of them. This might turn out to be problematic as Collier and Morgan (2008) stressed the importance of students understanding what professors expect of them, as student performance is ultimately graded by the supervisor (although in consultation with a second and independent assessor).

\section{Conclusion}

We conclude that in Master's thesis projects, supervisor goals, but more importantly that student goals exceed the scope of curricular goals and also include personal or human goals. This can be explained by students engaging in a transition from being a student to becoming a professional, which indicates that the timing of the thesis can be seen as complex. Secondly, we conclude that supervisor goals seem to have a somewhat different focus compared to student goals, with students focusing more on gaining knowledge and supervisors focusing on applying knowledge. Still, in several instances supervisors and students do pursue a shared goal. Thirdly, we conclude that supervisors and students perceive each other's goals correctly in only a few cases. This might be worrying as the supervisors in this study had a local reputation of being good supervisors. Even though some supervisors correctly perceive that students want to get a diploma, they do not recognize the students personal goals. In general, the results of this study suggest that providing goal-related feedback in the context of Master's thesis projects might not be as straightforward as it is in the context of secondary education or courses in higher education in which the tasks are less complex, and the goals more clear.

\section{Limitations and implications}

Despite the interesting and sometimes surprising findings of this study, some limitations need to be addressed. In the present study only a small sample was included from one university in the Netherlands, but we did include students from three departments. As students from different fields of study can have different life goals (Garciá-Aracil, Gabaldo, Mora, \& Vila, 2007; Mikkonen et al., in press), it is also possible that they have different goals in relation to a Master's thesis. In addition, the supervisors participating in this study were selected because of their local reputation for being good supervisors. For these two reasons, our findings cannot be generalized to other departments, universities, countries, or supervisory settings. Future studies need to investigate this set of goals further in other, preferably larger and more heterogeneous samples. The results of this study therefore, should be considered to represent a single instance of student and supervisor goals as pursued and perceived.

Students and supervisors were interviewed only once, and in different phases of the thesis project. This indicates that the presented findings resulted in an instantaneous sample, which might be oversimplified as Ford (1992) indicated that goals can change over time.

Despite these limitations, some practical implications can be drawn from this study. Our findings indicate to some extents an incongruence of goals for supervisors and their students, implying that communication about goals should be enhanced in thesis projects. More specifically, as our findings indicate that students often do not have a congruent idea of their supervisor's goals, it seems important for supervisors to pay (even) more attention to discussing and aligning their goals with students. The first supervision meeting is potentially a good time to discuss curricular, supervisor, and student goals. However, this might not be enough, as goals might change over time. Therefore, we deem it important that goals are explicitly addressed on a regular basis during the supervision process, by linking feedback explicitly to the various and sometimes evolving goals. Also, it might be beneficial for students if supervisor feedback is related not only to curricular goals, but also to personal goals as students do not only pursue curricular goals but may have various personal goals for which they strive. This is not surprising, given the fact that Master's thesis students are in a transitional phase from student to graduate and most likely will enter the labour market soon after graduating. 


\section{Acknowledgment}

The authors would like to thank Chesten Breijer for his help with transcribing the interview data and Larike Bronkhorst, Niek van den Bogert, and Marloes Hendrickx for their valuable help and advice during the analyses of data.

\section{References}

Anderson, C., Day, K., \& McLaughlin, P. (2008). Student perspectives on the dissertation process in a Master's degree concerned with professional practices. Studies in Continuing Education, 30, 33-49. http://dx.doi.org/10.1080/01580370701841531

Anderson, C., Day, K., \& McLaughlin, P. (2006). Mastering the dissertation: lecturers' representations of the purposes and processes of Master's level dissertation supervision. Studies in Higher Education, 31, $149-168$. http://dx.doi.org/10.1080/03075070600572017

Carver, C. S., \& Scheier, M.F. (2000). On the structure of behavioural self-regulation. In M. Boekaerts, P.R. Pintrich, \& M.. Zeidner (Eds.), Handbook of self-regulation (pp. 41-84). San Diego, CA: Academic. http://dx.doi.org/10.1016/B978-012109890-2/50032-9

Collier, P.J., \& Morgan, D.L. (2008). “Is that paper really due today?”: differences in first-generation and traditional college students' understandings of faculty expectations. Higher Education, 55, 425-446. http://dx.doi.org/10.1007/s10734-007-9065-5

Ford, M.E. (1992). Motivating humans: Goals, emotions, and personal agency beliefs. Hillsdale, NJ: Erlbaum.

Ford, M.E., \& Nichols, C.W. (1987). A taxonomy of human goals and some possible applications. In M.E. Ford \& D.H. Ford (Eds.), Humans as self-constructing systems: Putting the framework to work (pp. 289-311). Hillsdale, NJ: Erlbaum

Ford, M.E., \& Nichols, C.W. (1991). Using goal assessment to identify motivational patterns and facilitate self-regulation. In M.L. Maehr \& P.R. Pintrich (Eds.). Advances in achievement and motivation (Vol. 7, pp. 51-84). Greenwich, CT: JAI Press.

Ford, M.E., \& Smith, P.R. (2007). Thriving with social purpose: an integrative approach to the development of optimal human functioning. Educational Psychologist, 42, 153-171. http://dx.doi.org/10.1080/00461520701416280

Gänzle, S., Meister, S., \& Kind, C. (2009). The Bologna process and its impact on higher education at Russia's margins: the case of Kaliningrad. Higher Education, 57, 533-547. http://dx.doi.org/10.1007/s10734-008-9187-4

Garcia-Aracil, A., Gabaldo, D., Mora, J.G., \& Vila, L.E. (2007). The relationship between life goals and fields of study among young European graduates. Higher Education, 53, 843-865. http://dx.doi.org/10.1007/s10734-005-7517-3

Hattie, J., \& Timperley, H. (2007). The power of feedback. Review of educational research, 77, 81-112. http://dx.doi.org/10.3102/003465430298487

Joint Quality Initiative. (2004). Shared 'Dublin' descriptors for short cycle, first cycle, second cycle and third cycle awards. Retrieved on: www.jointquality.nl/content/CompletesetDublinDescriptors.doc.

Kleijn, R.A.M. de, Mainhard, M.T., Meijer, P.C., Pilot, A., \& Brekelmans, M. (2012). Master's thesis supervision: Relations between perceptions of the supervisor-student relationship, final grade, perceived supervisor contribution to learning and student satisfaction. Studies in Higher Education, 37, 925-939. http://dx.doi.org/10.1080/03075079.2011.556717

Kleijn, R.A.M. de, Mainhard, M.T., Meijer, P.C., Brekelmans, M., \& Pilot, A. (2012). Master's thesis projects: Student perceptions of supervisor feedback. Manuscript submitted for publication.

Litmanen, T., Hirsto, L., \& Lonka, K. (2010). Personal goals and academic achievement among theology students. Studies in Higher Education, 35, 195-208. http://dx.doi.org/10.1080/03075070902995205

Livanos, I. (2010). The relationship between higher education and labour market in Greece: the weakest link? Higher Education, 60, 473-489. http://dx.doi.org/10.1007/s10734-010-9310-1

Lovitts, B.E. (2007). Making the implicit explicit: Creating performance expectations for the dissertation. Sterling, VA: Stylus. 
Marita, J., \& Felix, W. (2010). From higher education to work patterns of labor market entry in Germany and the US. Higher Education, 60, 529-542. http://dx.doi.org/10.1007/s10734-010-9313-y

Meeus, W., Van Looy, L., \& Libotton, A. (2004). The bachelor's thesis in teacher education. European Journal of Teacher Education, 27, 299-321. http://dx.doi.org/10.1080/0261976042000290813

Mikkonen, J., Ruohoniemi, M., \& Lindblom-Ylänne, S. (in press). The role of individual interest and future goals during the first years of university studies. Studies in Higher Education. http://dx.doi.org/10.1080/03075079.2011.564608

Murphy, N. (2009). Research supervision: matches and mismatches. International Journal of Electrical Engineering Education, 46, 295-306.

Murtonen, M., Olkunuora, E., Tynjäla, P., \& Lethninen, E. (2008). "Do I need research skills in working life?": University students' motivation and difficulties in quantitative methods courses. Higher Education, 56, 599-612. http://dx.doi.org/10.1007/s10734-008-9113-9

Nelson, M.L., \& Friedlander, M.L. (2001). A close look at conflictual supervisory relationships: the trainee's perspective. Journal of Counseling Psychology, 48, 384-395. http://dx.doi.org/10.1037/0022-0167.48.4.384

Pintrich, P.R. (2004). A conceptual framework for assessing motivation and self-regulated learning in college students. Educational Psychology Review, 16, 385-409. http://dx.doi.org/10.1007/s10648-004-0006-x

Schwartz, S.H. (1992). Universals in the content and structure of values. In M.P. Zanna (Ed.), Advances in experimental social psychology (Vol. 25, pp. 1-65). New York: Academic.

Todd, M., Bannister, P., \& Clegg, S. (2004). Independent inquiry and the undergraduate dissertation: perceptions and experiences of final-year social science students. Assessment and Evaluation in Higher Education, 29, 335-355. http://dx.doi.org/10.1080/0260293042000188285

Ylijoki, O.H. (2001). Master's thesis writing from a narrative approach. Studies in Higher Education, 26, 21-34. http://dx.doi.org/10.1080/03075070020030698 